Д. В. Мазилкин. Вопросы организации и производства экспертиз по факту неоказания или ненадлежащего оказания медицинской помощи...

Научная статья

УДК 34:616 (571.55)

DOI 10.18101/2658-4409-2021-2-15-19

\title{
ВОПРОСЫ ОРГАНИЗАЦИИ И ПРОИЗВОДСТВА ЭКСПЕРТИЗ ПО ФАКТУ НЕОКАЗАНИЯ ИЛИ НЕНАДЛЕЖАЩЕГО ОКАЗАНИЯ МЕДИЦИНСКОЙ ПОМОЩИ (по данным следственного управления Следственного комитета России по Забайкальскому краю) ${ }^{* 1}$
}

\author{
(C) Мазилкин Дмитрий Валерьевич \\ эксперт Дальневосточного филиала ФГКУ СЭЦ СК России \\ Россия, 672010, г. Чита, ул. Ингодинская, 32 \\ otdoksu@yandex.ru
}

\begin{abstract}
Аннотация. В расследовании преступлений ятрогенной направленности важное место отводится судебно-медицинской экспертизе. Анализируются распространенные в практике проблемы выбора вида и места проведения судебно-медицинской экспертизы. Наиболее распространенной практикой является назначение судебно-медицинской экспертизы качества гинекологической и акушерской помощи и хирургического вмешательства. Рассматриваются наиболее распространенные проблемы судебномедицинской экспертизы при правовой оценке и квалификации неоказания или ненадлежащего оказания медицинской помощи.

Ключевые слова: расследование преступлений, неоказание медицинской помощи, ненадлежащее оказание медицинской помощи, назначение судебно-медицинской экспертизы, повторное назначение судебно-медицинской экспертизы, ятрогенные преступления, виды судебно-медицинских экспертиз.
\end{abstract}

\section{Для цитирования}

Мазилкин Д. В. Вопросы организации и производства экспертиз по факту неоказания или ненадлежащего оказания медицинской помощи (по данным следственного управления следственного комитета России по Забайкальскому краю) // Вестник Бурятского государственного университета. Юриспруденция. 2021. Вып. 2. С. 15-19.

Расследованию преступлений, связанных с ненадлежащим оказанием медицинской помощи гражданам сотрудниками Следственного комитета Российской Федерации, уделяется пристальное внимание. Среди медицинских работников бытует мнение, что в отношении медиков действует некая компания, однако количество поступающих от граждан обращений на ненадлежащее оказание медицинской помощи и количество направленных в суды уголовных дел по обвинению врачей в совершении преступлений, предусмотренных ч. 2 ст. 109, ч. 2 ст. 118 УК РФ, свидетельствует о том, что проблема ненадлежащего оказания медицинской помощи имеется.

В истекшем периоде 2019 г. следователями Следственного комитета РФ возбуждено 1690 уголовных дел ятрогенной направленности (АППГ-1560), в суд

\footnotetext{
Статья составлена по материалам доклада, подготовленного автором для участия в межрегиональной научно-практической конференции «Ответственность медицинских работников при оказании (неоказании) медицинской помощи», организованной юридическим факультетом БГУ с участием Следственного комитета России по Республике Бурятия и Министерством здравоохранения Республики Бурятия в ноябре 2019 г.
} 
направлено 220 уголовных дел (АППГ-180), прекращено 1220 уголовных дел (АППГ-980). За 10 месяцев 2019 г. в производстве следователей следственного управления по Забайкальскому краю находилось 42 уголовных дела ятрогенной направленности (АППГ-39); в суд направлено 10 уголовных дел (АППГ-9), прекращено в связи с отсутствием события и состава преступления 12 (АППГ-9).

Так, по десяти направленным в 2019 г. уголовным делам в суд было проведено 14 комиссионных судебно-медицинских экспертиз. Повторные экспертизы проводились в трех случаях (в экспертных учреждениях г. Москвы, Иркутской области и Ханты-Мансийском автономном округе). В первом случае при производстве экспертизы экспертами другого региона были представлены диаметрально противоположные выводы (первоначальная экспертиза, проведенная в ГУЗ «Забайкальское краевое бюро судебно-медицинской экспертизы», не показала наличие причинно-следственной связи), впоследствии судом было вынесено решение о прекращении уголовного дела в связи с истечением срока давности. По 12 прекращенным делам проведены 26 экспертиз, из них 16 экспертными учреждениями расположенными за переделами Забайкальского края (г. Хабаровск, Новосибирск, Ханты-Мансийск, Архангельск, Москва, Биробиджан). По всем находящимся в настоящее время в производстве уголовным делам назначены комиссионные судебно-медицинские экспертизы, из которых восемь назначены в экспертные учреждения, находящиеся за пределами Забайкальского края (Республика Бурятия, г. Ханты-Мансийск, Архангнельск, Астрахань, Хабаровск).

По направленным в суд за аналогичный период 2018 г. по девяти уголовным делам было проведено двенадцать комиссионных судебно-медицинских экспертиз, из которых три проведены экспертными учреждениями, расположенными за пределами Забайкальского края (Республика Бурятия, г. Иркутск, Архангельск). По прекращенным двенадцати уголовным делам были проведены 23 комиссионные судебно-медицинские экспертизы, из которых 13 выполнены экспертными учреждениями, расположенными за пределами Забайкальского края (Республика Бурятия, г. Иркутск, Архангельск, Хабаровск, Красноярск, Новосибирск, Москва, Ханты-Мансийск).

Причины назначения повторных экспертиз в соседние регионы не всегда связаны с некачественным проведением первичных в ГУЗ «Забайкальское краевое бюро судебно-медицинской экспертизы», частая причина их проведения обусловлена требованиями потерпевших с мотивировкой «о заинтересованности экспертов своего региона в исходе дела». В некоторых случаях возможности Забайкальского края не позволяют провести экспертизы по причине отсутствия соответствующих специалистов клинического профиля, либо по причине того, что все специалисты принимали участие в оказании медицинской помощи потерпевшему.

При назначении экспертиз в соседние регионы управление часто сталкивается с формальными отказами в производстве экспертиз (руководители экспертных учреждений ссылаются на финансовую дисциплину, отсутствие специалистов, загруженность экспертов недофинсирование и т. д.).

В ответе на запрос о производстве повторной экспертизы в ФГБУ «Российский центр судебно-медицинской экспертизы» от 15.10.2019 директор А. В. Ковалев указывает, что каждое экспертное учреждение имеет возможность и обязанность 
Д. В. Мазилкин. Вопросы организации и производства экспертиз по факту неоказания или ненадлежащего оказания медицинской помощи...

принимать к производству экспертизы следственных управлений соседних регионов в случае невозможности их производства силами своего региона. Следственное управление СК России по Забайкальскому краю неоднократно обращалось в Приморское бюро судебно-медицинской экспертизы, Бюро СМЭ г. Иркутска, Кемеровской области, г. Красноярска, Амурской области, Республики Тыва и т. д. От руководителей всех названных бюро были получены отказы.

На сегодняшний день, имея определенный опыт расследования уголовных дел ятрогенной направленности, можно сказать о том, что наиболее часто к уголовной ответственности привлекаются врачи-акушеры, гинекологи и врачи-хирурги. За период 2018-2019 гг. следственным управлением направлено в суд четыре уголовных дела по факту причинения вреда здоровью новорожденных в процессе родоразрешения (по ст. 118 УК РФ по факту причинения вреда здоровью новорожденных детей - 2; по ст. 109 УК РФ - 2). Также направлено в суд два уголовных дела по ст. 118 УК РФ, где согласно п. 6.7 «Медицинских критериев определения степени тяжести вреда, причиненного здоровью человека», утвержденных приказом Министерства здравоохранения и социального развития Российской Федерации от 24.04.2008 № 194н роженицам путем прерывания беременности прекращения течения беременности, вызванным внутриутробной гибелью плода причинен тяжкий вред здоровью.

Так, при оказании в 2017 г. медицинской помощи одной из беременных проведена операция «кесарево сечения» без антибиотикопрофилактики, что явилось последствием развития «гнойно-некротического эндометрита», в результате чего женщине выполнена экстерпация матки. В данном же лечебном учреждении в 2017 г. неправильно выбрана тактика родоразрешения, имеющей в анамнезе двое родов путем проведения операции «кесарево сечение». В результате консервативного родоразрешения случился разрыв матки, острый дистресс плода, что явилось следствием необратимых нарушений и смерти ребенка. Потерпевшей выполнена экстерпация матки. По данному уголовному делу врачи признаны виновными в совершении преступлений, предусмотренных ч. 2 ст. 109, ч. 2 ст. 118 УК РФ. Кроме того, в январе 2017 г. при проведении туалета новорожденному в условиях отделения новорожденного медицинская сестра умышленно оставила три спиртовых салфетки во влагалище ребенка, чем причинила легкий вред здоровью и необратимые последствия. По данному уголовному делу медицинская сестра признана виновной в совершении преступлений, предусмотренных ч. 1 ст. 115, ст. 125 УК РФ.

Несмотря на то, что следствием по каждому из данных случаев вносились в лечебное учреждение и Министерство здравоохранения Забайкальского края представления об устранении причин и условий, способствовавших совершению преступления, в которых в том числе ставился вопрос о соответствии занимаемой должности вышеуказанных врачей. По результатам рассмотрения представлений требования следствия удовлетворены не были, врачи продолжают оказывать медицинскую помощь роженицам.

При расследовании данной категории уголовных дел следствию приходится сталкиваться с противодействием со стороны медицинских работников, в том числе Министерства здравоохранения края, зачастую несмотря на то, что следствием 
путем проведения следственных действий устанавливаются явные нарушения, повлекшие тяжкие последствия, однако по итогу медицинских разборов случаи признаются неуправляемыми без дефектов оказания медицинской помощи.

Результаты проведения такого вида судебно-медицинских экспертиз до настоящего времени продолжают оставаться спорными, сами экспертизы наукоемкими, а тенденция к росту их назначения продолжает сохраняться. Одной из основных организационно-процессуальных проблем их проведения, в том числе обусловливающих их длительность, является необходимость привлечения в состав экспертной комиссии не находящихся в штате государственных судебно-медицинских экспертных учреждений высококвалифицированных, постоянно практикующих специалистов клинического профиля, работающих в медицинских организациях системы здравоохранения и в учреждениях высшего профессионального медицинского образования. Фактически, это комплексные, а не комиссионные экспертизы, требующие применения различных специальных познаний в области медицины и фармации.

Вышеизложенное свидетельствует о наличии неудовлетворенности населения Забайкальского края качеством оказания медицинской помощи, что порождает рост обращений в правоохранительные органы, а значит, и возрастают требования к экспертной службе в Российской Федерации.

\section{Литература}

1. Кузнецов С. В. Порядок организации и производства судебно-медицинских экспертиз оказания медицинской помощи // Медицинское право. 2017. № 3(73). С. 24-29. Текст : непосредственный.

2. Возможности выполнения судебно-медицинских экспертиз по «врачебным» уголовным делам собственными экспертными силами Главного следственного управления СК РФ по городу Санкт-Петербургу / С. В. Кузнецов [и др.]. // Медицинское право. 2017. № 4(74). С. 45-48. Текст : непосредственный.

3. Альшевский В. В. Судебно-медицинская экспертиза вреда здоровью в современном уголовном судопроизводстве (процессуальные аспекты, методические принципы и формально-логические алгоритмы). Москва : Юрлитинформ, 2004. 176 с. Текст : непосредственный.

4. Исаков В. Д. Профессиональные правонарушения медицинских работников и судебная экспертиза. Санкт-Петербург, 2004. 114 с. Текст : непосредственный.

Статья поступила в редакцию 15.04.2021; одобрена после рецензирования 12.05.2021; принята к публикации 22.06.2021.

ISSUES OF ORGANIZATION AND PERFORMANCE OF EXPERT EXAMINATION ON FAILURE TO PROVIDE MEDICAL CARE AND INAPPROPRIATE MEDICAL CARE (according to Investigative Department of the Investigative Committee of the Russian Federation in Zabaikalsky Krai)

Dmitriy V. Mazilkin

Expert of the Far Eastern branch of Judicial Expert Center of the Investigative Committee of the Russian Federation 
Д. В. Мазилкин. Вопросы организации и производства экспертиз по факту неоказания или ненадлежащего оказания медицинской помощи...

32 Ingodinskaya St., Chita 672010, Russia

otdoksu@yandex.ru

Abstract. Forensic examination plays an important role in investigation of iatrogenic crimes. The article analyzes the widespread problems of choosing the type and place of forensic examination. The most common practice is commissioning of forensic examination of the quality of gynecological and obstetric care as well as surgical intervention. We have considered the widespread problems of forensic examination in legal assessment and classification of failure to provide medical care and inappropriate medical care.

Keywords: crime investigation, failure to provide medical care, inappropriate medical care, commissioning of forensic examination, recommissioning of forensic examination, iatrogenic crimes, types of forensic examination

\section{For citation}

Mazilkin D. V. Issues of Organization and Performance of Expert Examination on Failure to Provide Medical Care and Maltreatment (according to Investigative Department of the Investigative Committee of the Russian Federation in Zabaikalsky Krai). Bulletin of Buryat State University. Law. 2021; 2: 15-19 (In Russ.).

The article was submitted 15.04.2021; approved after reviewing 12.05.2021; accepted for publication 22.06.2021. 